\title{
Technical Efficiency of Red Pepper Production: The Case of Dalocha District, Southern Ethiopia
}

\author{
Degineh Lagiso $^{1} \quad$ Endrias Geta $^{2} \quad$ Workalemahu Tasew ${ }^{3}$ Hana Mamo $^{4}$ \\ 1.Lecturer at department of Agricultural Economics, Werabe University, Werabe, Ethiopia \\ 2.Researcher at Southern Agricultural Research Institute, Hawassa, Ethiopia \\ 3.Lecturer at school of Environment, Gender and Development Studies, Hawassa University, Hawassa, Ethiopia \\ 4.Lecturer at department of Agricultural Economics, Werabe University, Werabe, Ethiopia
}

\begin{abstract}
Increasing the productivity of red pepper is important to meet the need of ever increasing population. However, farmers faced the problem of productivity due to the lack of knowledge on how to maximize level of output at a given level of inputs. The objective of this study was to assess the technical efficiency of red pepper production in Dalocha district of southern Ethiopia. Cobb-Douglas stochastic frontier model was used to estimate the technical efficiency and its determinants in red pepper production. Maximum likelihood estimation results showed that increasing input variables (oxen power, seed, labor and fertilizer) would increase yield of red pepper. The discrepancy ratio, $\gamma$, which measures the relative deviation of output from the frontier level due to inefficiency was about 85 percent indicating that about $85 \%$ of variation in red pepper yield among the farmers was attributed to technical inefficiency effects. The mean technical efficiency of farmers was about $80 \%$. The implication is that, there is an opportunity to improve technical efficiency among farmers on average by $20 \%$ through efficient use of inputs. Thus, it is possible to improve technical efficiency through utilizing available inputs wisely.
\end{abstract}

Keywords: Red Pepper, Technical Efficiency, Cobb-Douglas stochastic frontier.

DOI: $10.7176 /$ IEL/10-1-01

Publication date: January $31^{\text {st }} 2020$

\section{Introduction}

Red pepper is cash crop for many developing countries, such as Ethiopia, Nigeria, Ghana, China, India, Pakistan, Bhutan, Indonesia, Cambodia and Thailand (Shih-wen et al., 2013). Investment in pepper production is viable enterprise for income generation, poverty alleviation, job creation and improvement of food security to every household (Mohammed et al., 2015). The study shows that pepper is the world's second important vegetable ranking after tomatoes. It is the commonly produced type of spice, flavoring and colouring to food while providing essential vitamins and minerals and has substantial nutritional value (Mussema, 2006). However, it is leading vegetable and spice in Ethiopia (CSA, 2016).

Ethiopia has a favourable climatic and soil conditions for pepper production. The most commonly grown types are Mareko Fana, a pungent long chilli of dark-red smaller mitmita, chillies, hot, red and small pepper (Herms, 2015).

According to CSA (2016), vegetables production covers $1.44 \%$ of the area under all crops at national level. From the total estimated area under vegetables production, the lion share which is about $70.93 \%$ was under red pepper production.

Efficient utilization of various resources helps to achieve the optimum level of production. But, various constraining factors, natural (weather, disease and pests) and human factors (knowledge gap) expose farmers for inefficiency on their farming activities. In Ethiopia, various efforts have been made in agricultural sector but its performance is still weak and stays at subsistent level. Conversely, the increasing number of population in the country has led to increase the demand for food. To balance these two, the important option is that, improving productivity of farmers by providing modern technologies and advices on how to produce it optimally and efficiently.

The trends of productivity of red pepper production in Ethiopia showed little increase from 1.625 metric ton per hectare in 2007 to 1.84 metric ton per hectare in 2015 (CSA, 2008 and 2016). However, required level of productivity is not achieved due to various constraints. When we compare the yield obtained in the years of 2011 and 2015 were 2.201 and 1.84 metric tonnes per hectare respectively (CSA, 2012 and 2016). The available constraints hinder the achievements of potential levels of output, which includes usage of retained seed, disease and shortage of pesticide to control pests. Similarly, main constraints that contributed for low productivity of pepper in Ethiopia are shortage of improved varieties, lack of proper and adequate inputs (i.e. pesticides) and lack of research outputs on production techniques (Lemma et al., 2008). In addition, shortage of irrigation system, inadequate rainfall, disease and pests adversely affect productivity of red pepper production (Alemnew, 2010). Furthermore, improper use of farming land and rainfall dependent agriculture is influential factors for low productivity (Ahmed et al., 2013). By considering this, hindrances which lock farmers' technical efficiency in the Dalocha district of southern Ethiopia need to be identified. With regard to this issue, technical efficiency study in 
red pepper production is an essential issue because it provides pertinent information for making good management decision in resource utilization.

\section{Research Methology}

\subsection{Description of the Study Area}

The study was undertaken in Dalocha district, Siltie zone of Southern Ethiopia. The agro-climate zone of the area is Woina-dega and their livelihood of the district is based on crop and livestock production. The main crops grown in the area were red pepper, wheat, maize, sorghum, teff, bean and barley while livestock reared by farmers are cattle, small ruminants, chicken and donkey. The annual rainfall ranges from 700 to $1000 \mathrm{~mm}$ with annual temperature ranging from $26^{\circ} \mathrm{C}$ to $28^{\circ} \mathrm{C}$. The averag e altitude of the area ranges between $1000-1980$ m.a.s.l. (BOFED, 2012)

\subsection{Data Type, Sources and Methods of Data Collection}

Qualitative and quantitative data from primary and secondary sources were collected for analysis. Primary data were collected directly from farmers and experts. The major instrument for collecting the primary data was semistructured questionnaire. Before data collection, the questionnaire was pre-tested on 10 farmers to evaluate the appropriateness of the data, clarity and relevance of the questions. Hence, appropriate modifications and corrections were undertaken and then it was collected under supervision of researcher. Secondary data were gathered from documented sources such as journal articles, books, thesis, dissertation and bureau of agriculture.

\subsection{Sample Size and Sampling Technique}

A two stage sampling procedure was employed to select sample from red pepper producing farmers in the study area. In the first stage, four kebeles were selected purposively based on the extent of red pepper production. In the second stage, the sample farmers were selected using simple random sampling technique from the list of each kebele pepper farmers relative to size of their population. Then, 170 red pepper producing households were used for the study.

The sample size was determined by using formula given by Yamane (1967) that is:

$$
\mathbf{n}=\frac{\mathbf{N}}{\mathbf{1 + N}(\mathbf{e}) \mathbf{2}}
$$

Where, $\mathrm{n}$ is sample size, $\mathrm{N}$ is total number of red pepper growers in the selected kebeles and e is desired level of precision i.e. taking e as $7 \%$ and $\mathrm{N}$ as 990

Table 1. Red pepper producing farmers sampling frame.

\begin{tabular}{llll}
\hline No. & Name of the kebele & Total number of pepper growers & Sample farmer $(17 \%)$ \\
\hline 1 & Dubegodabamo & 242 & 42 \\
2 & Golacaba & 278 & 48 \\
3 & Hipoterora & 287 & 49 \\
4 & Wanjashola & 183 & 31 \\
& Total & 990 & 170 \\
\hline
\end{tabular}

\subsection{Methods of Data Analysis}

The analytical techniques used were descriptive statistics such as percentage, frequency, mean, minimum, maximum and standard deviation analysis and econometric model i.e., Cobb-Douglas stochastic frontier model.

\subsubsection{Technical efficiency analysis}

The Cobb- Douglas functional form of production functions is widely used to represent the relationship of an output to inputs. To estimate the technical efficiency of red pepper producers, Cobb-Douglas stochastic frontier production function model was used. The model is illustrated as follows:

$\mathrm{Y}_{\mathrm{i}}=\mathrm{AX}_{1}{ }^{\beta 1} \mathrm{X}_{2}{ }^{\beta 2} \ldots \ldots \ldots . \mathrm{e}^{\mathrm{ui}}$

Where, $\mathrm{Y}_{\mathrm{i}}=$ the level of output produced by $i^{\text {th }}$ farmer measured in kilogram, $\mathrm{X}_{\mathrm{i}}=$ input used by $i^{\text {th }}$ farmer to produce red pepper, $\beta_{i}=$ unknown parameters to be estimated, $u_{i}=$ error term and $e_{i}=$ base of natural logarithm.

The natural logarithmic form of the model is given by:

$\ln \left(Y_{i}\right)=\beta_{o}+\beta_{1} \ln$ AREA $_{i}+\beta_{2} \operatorname{lnOXN}_{i}+\beta_{3} \ln \operatorname{SEED}_{\mathrm{i}}+\beta_{4} \ln \ln \mathrm{B}_{\mathrm{i}}+\beta_{5} \ln \operatorname{lERT}_{\mathrm{i}}+\mathrm{V}_{\mathrm{i}}-\mathrm{U}_{\mathrm{i}}$

Where,

$\mathrm{AREA}_{\mathrm{i}}=$ operational area red pepper of the $i^{\text {th }}$ plot in hectare,

$\mathrm{OXN}_{\mathrm{i}}=$ total oxen power in oxen-days (amount of oxen days used for ploughing from land preparation to planting and transplanting) utilized,

$\mathrm{SEED}_{\mathrm{i}}=$ seed used in kilogram,

$\mathrm{LAB}_{\mathrm{i}}=$ total human labor in man-days utilized,

$\mathrm{FERT}_{\mathrm{i}}=$ total amount of fertilizer used in kilogram, $\mathrm{V}_{\mathrm{i}}=$ random error term of the model and $\mathrm{U}_{\mathrm{i}}=$ non-negative random variable associated with technical inefficiency in production of farmers. 
Technical efficiency of each farmer is estimated as:

$\mathrm{TE}_{\mathrm{i}}=\mathrm{Y}_{\mathrm{i}} / \mathrm{Yi}^{*}$

Where, $\mathrm{TE}_{\mathrm{i}}=$ technical efficiency of the $i^{\text {th }}$ farmer in red pepper production.

$\mathrm{Y}_{\mathrm{i}}=$ observed or actual output of the $i^{\text {th }}$ farmer in red pepper production and

$\mathrm{Yi}^{*}=$ frontier or potential output of the $i^{\text {th }}$ farmer in red pepper production

The inefficiency model is specified as:

$\mathrm{U}_{\mathrm{i}}=\delta_{0}+\delta_{1} \mathrm{AG}_{\mathrm{i}}+\delta_{2} \mathrm{EDU}_{\mathrm{i}}+\delta_{3} \mathrm{FAM}_{\mathrm{i}}+\delta_{4} \mathrm{FE}_{\mathrm{i}}+\delta_{5} \mathrm{EX}_{\mathrm{i}}+\delta_{6} \mathrm{CR}_{\mathrm{i}}+\delta_{7} \mathrm{LS}_{\mathrm{i}}+\delta_{8} \mathrm{TLU}_{\mathrm{i}}+\delta_{9} \mathrm{SEX}_{\mathrm{i}}+$ $\delta_{10} \mathrm{FRAG}_{\mathrm{i}}+\delta_{11} \mathrm{DSMT}_{\mathrm{i}}+\delta_{11} \mathrm{OFFARM}_{\mathrm{i}}$

Where, $\mathrm{U}_{\mathrm{i}}=$ technical inefficiency of $i^{\text {th }}$ farmer, $\delta=$ parameter to be estimated, $\mathrm{AG}_{\mathrm{i}}=$ age of farmer in years, EDU $=$ educational level of farmer (year of schooling), $\mathrm{FAM}_{\mathrm{i}}=$ family size in labor force unit, $\mathrm{FE}_{\mathrm{i}}=$ experience of red pepper farming in year, $\mathrm{EX}_{\mathrm{i}}=$ extension contact in frequency of visit; $\mathrm{CR}_{\mathrm{i}}=$ a dummy variable with a value of 0 if farmers get credit, 1 otherwise, $\mathrm{LS}_{\mathrm{i}}=$ size of land holding in hectare, $\mathrm{TLU}_{\mathrm{i}}=$ livestock in tropical livestock unit, $\mathrm{SEX}_{\mathrm{i}}=$ a dummy variable with a value of 0 if $i^{\text {th }}$ farmer is male, 1 otherwise, $\mathrm{FRAG}_{\mathrm{i}}=$ plot of land in number of plot, $\mathrm{DSMT}_{\mathrm{i}}=$ distance to nearest market in waking hours and $\mathrm{OFFARM}_{\mathrm{i}}=$ a dummy variable with a value of 0 if $i^{\text {th }}$ farmer earn off/non-farm occupation, 0 otherwise.

One-stage estimation procedure of the inefficiency effect model together with production frontier function was used to analyze the data. This estimation procedure is widely used to estimate input variables and inefficiency effects simultaneously than two-stage estimation procedure. Because it doesn't violates distributional assumption of inefficiency effects (Coelli et al., 1998). Similarly, Battese and coelli (1995) proposed one-stage estimation procedure than two-stage estimation procedure. They explain two-stage estimation procedure as it violates that of identically independently distributed technical inefficiency effects in stochastic frontier. So, the one-stage estimation procedure was preferred for the study. STATA version 12, SPSS version 20 and Microsoft excel 2010 were used to analyze the data.

\subsubsection{Hypothesis testing}

The following null hypotheses for choice of frontier production function and efficiency model were tested in this study

1) $\mathrm{H}_{0}: \gamma=\delta_{0}=\delta_{1}=\ldots \ldots=\delta_{12}=0$, null hypothesis specifies that inefficiencies are absent from the model at every level;

2) $\mathrm{H}_{0}: \delta_{0}=\delta_{1}=\ldots \ldots=\delta_{12}=0$, null hypothesis specifies that inefficiency effects are not a linear function of each of the inefficiency factors.

The approach which is used to test hypothesis associated with presence or absence of technical inefficiency is specified as:

$$
\begin{aligned}
L R=\lambda & =-2 \ln \left[L\left(H_{0}\right) / L\left(H_{1}\right)\right] \\
\lambda & =-2\left[\ln L\left(H_{0}\right)-\ln L\left(H_{1}\right)\right]
\end{aligned}
$$

Where, $\mathrm{L}\left(\mathrm{H}_{0)}\right.$ and $\mathrm{L}\left(\mathrm{H}_{1}\right)$ Values of the likelihood function under the null (restricted) and alternative (unrestricted) hypothesis, $\mathrm{H}_{0}$ and $\mathrm{H}_{1}$ respectively. The null hypothesis determines whether the variables included in the inefficiency effects model have no effect on the level of technical inefficiency while reverse is true for the alternative hypothesis. The $\mathrm{H}_{0}$ is rejected when the estimated chi-square is greater than the critical value (Wudineh and Endrias, 2016). Some of the researchers who have used the stochastic frontier approach are Gelaw (2004); Hailsellasie (2005); Ahmed et al. (2013) and Wudineh and Endrias (2016).

\section{Results and Discussion}

This section discussed the specified variables included in the model using descriptive statistics and econometric analysis. The descriptive statistics briefly describe results of demographic, socio-economic, farm characteristics and institutional factors by average, percentage, standard deviation, minimum and maximum while econometric model such as cobb-Douglas stochastic model was employed to estimate technical efficiency with its determinants simultaneously.

\subsection{Descriptive Statistics}

Factors of red pepper production were described in the table. The majority of farmers were found in active and energetic age which the mean value was 32.94 found in between 22 and 46 with deviation of 6.306 (Table 2) and they are considered as economically active force to achieve its work effectively and efficiently. The mean of family size is 2.66 which found in between 1 and 5.56 (6 person) with standard deviation of 0.905 (Table 2). The family size of the farmers in the study was converted into labor force unit to differentiate those who can perform agricultural activities from those who cannot.

Regarding the level of education, the average was 4.523 ranging between 0 and 12 with standard deviation of 3.23 (Table 2). This elaborate that, some sampled farmers were not attending formal education while others attending their education from grade one to grade twelve in their locality. This implies that the farmers are still not 
fully participated in formal educations, which help them to adopt new production technology and practices.

The average period of time the farmers got advices from development agents was 4.97 ranges from 0 to 15 with standard deviation of 3.33(Table 2). This shows that the farmers addressed by extension agents to provide advices on how to manage agricultural production were less uniform among farmers. This leads to widen the efficiency variation among farmers in the study area. The maximum time to arrive the market is 3 hours and 20 minutes relative to minimum of 28 minutes (Table 2). This indicated that some farmers faced the problem of market to sell their products due to their home is found a place where it far from the market.

Table 2. Descriptive statistics for continuous variables used in the analysis

\begin{tabular}{lllll}
\hline Variable & Mean & Standard dev. & Min & Max \\
AGE & 32.94 & 6.306 & 22 & 46 \\
EDU & 4.523 & 3.23 & 0 & 12 \\
FAM & 2.66 & 0.905 & 1 & 5.56 \\
FE & 14.37 & 5.98 & 1 & 28 \\
EX & 4.97 & 3.33 & 0 & 15 \\
LS & 1.26 & 0.803 & .125 & 5 \\
TLU & 2.7 & 1.57 & 0 & 7.55 \\
FRAG & 2.89 & 0.86 & 1 & 5 \\
DSMT & 1.42 & 0.7 & 0.28 & 3.2 \\
\hline
\end{tabular}

Source: Own computation (2017)

The study revealed that 92.4 percent of the sampled red pepper farmers were male while remaining 7.6 percent were female (Table 3). This implies that red pepper production is dominated by male in the study area. Credit was provided in the form of input (i.e. fertilizer) indicating that about 95.3 percent of sampled farmers got fertilizer (Dap and Urea) during production season while 4.7 percent were purchased fertilizer in cash (Table 3). : Off-farm income is very important for contributing production of agricultural crops. The only 7.1 percent of sampled farmers were obtained off/non-farm occupation while the remaining 92.9 percent of farmers had no access to off/non-farm occupation in the study area (Table 3 ). This shows that the farmers had less access to off- /non-farm income generating activities.

Table 3. Descriptive statistics for discrete variables used in the analysis

\begin{tabular}{llll}
\hline \multicolumn{2}{l}{ Variable } & Frequency & Percent \\
\hline SEX & Male & 157 & 92.4 \\
& Female & 13 & 7.6 \\
CR & Accessed & 162 & 95.3 \\
& Non- access. & 8 & 4.7 \\
OFFARM Have & 12 & 7.1 \\
\multicolumn{2}{l}{ Haven't } & 158 & 92.9 \\
\hline
\end{tabular}

Source: Own computation (2017)

\subsection{Results of Econometric Analysis}

\subsubsection{Hypothesis testing}

The result presented in Table 4 revealed that the value sigma square and gamma are 0.11 and 0.85 respectively and hence null hypothesis $\left(\mathrm{H}_{0}: \gamma=0\right)$ is rejected indicating stochastic frontier production function is best fit to the data than OLS. This shows that the estimated sigma square and gamma were significantly different from zero. This also indicates a good fit and correctness of the specified distribution assumption of the composite error term and technical inefficiency effects are significant in the estimated model.

The second null hypothesis determines that explanatory variables associated with technical inefficiency effects model is all zero (i.e. $\mathrm{H}_{0}: \mathrm{U}_{\mathrm{i}}=\delta_{1}=\delta_{2}=\ldots \delta_{12}=0$ ). This hypothesis was tested by calculating likelihood ratio under the stochastic frontier model (a model without explanatory variables of inefficiency effects, $\mathrm{H}_{0}$ ) and the full frontier model ( a model with variables that are assumed to determine inefficiency of each pepper growing farmer, $\mathrm{H}_{1}$ ). The calculated value of likelihood ratio was found to be 48, which is higher than 21.026 critical values at 5\% significance level with 12 degree of freedom (Kodde and Palm, 1986). Thus, it shows that the explanatory variables associated with inefficiency effects model are simultaneously different from zero and hence, CobbDouglas stochastic production function was preferred.

\subsubsection{Estimation of parameters of SPF model}

In this study, five input variables were used for estimation of the frontier production function which includes the land area allocated to red pepper farms in hectare, oxen power utilized in oxen-days, seed in kilogram, fertilizer used (Dap and Urea) expressed in kilogram and labor utilized in man-days.

The result presented in Table 4 shows that ox, seed, labor and fertilizer were positive as expected and statistically significant but area allocated is negative sign which was unexpected sign and statistically insignificant. The coefficients of area, ox, seed, labor and fertilizer were $-0.173,0.31,0.087,0.47$ and 0.38 respectively. Except 
area allocated to red pepper, all these inputs have positive and significant contribution to the level of output, means that an increase in these inputs would increase output of red pepper. The sum of the estimated coefficients is 1.074 , indicating increasing return to scale in red pepper production in the study area. The higher elasticity of input variables would have greater impact in determining the level of output while the reverse is true for lower elasticity of input variables.

The elasticity of labor is very high implying labor has greater impact in determining production of red pepper. Consequently, this farm needs high amount of labor from land preparation to harvesting period. The harvesting period of red pepper usually overlap with other agricultural crops specially wheat crop. Thus, they face shortage of labor force. Coefficients of fertilizer (Dap and Urea) and oxen have relatively higher impacts in determining production level of farmers output as elasticity shows.

Table 4. Maximum likelihood estimates of the frontier model

\begin{tabular}{llll}
\hline Variable & Coefficient & Std. Err & Z \\
\hline Constant & $2.672^{* * *}$ & 0.595 & 4.49 \\
AREA & -0.173 & 0.142 & -1.22 \\
OXN & $0.31^{* * *}$ & 0.102 & 3.06 \\
SEED & $0.087^{* *}$ & 0.039 & 2.24 \\
LAB & $0.47^{* * *}$ & 0.109 & 4.29 \\
FERT & $0.38^{* * *}$ & 0.096 & 3.91 \\
\hline sigma_v $\left(\alpha_{\mathrm{v}}\right)=0.1269$ & & sigma_u $\left(\alpha_{\mathrm{u}}\right)=0.3067$ & sigma $^{2}\left(\alpha^{2}\right)=\alpha_{\mathrm{u}}{ }^{2}+\alpha \mathrm{v}^{2}=0.11$ \\
Lambda $\left(\lambda=\alpha_{\mathrm{u}} / \alpha_{\mathrm{v}}\right)=2.418$ & Number of obs. $=170$ &
\end{tabular}

$\operatorname{Gamma}\left(\gamma=\lambda^{2} /\left(1+\lambda^{2}\right)=0.85\right.$

Log likelihood function $=41.153$

Source: Own computation (2017). ** and *** mean significant at levels of 0.05 and 0.01 respectively.

Some literatures such as Mohammed et al. (2015), Wassie (2014) and Hailemaraim (2015) explain that fertilizer is an important input in increasing production and productivity level of agricultural crops. In the study area, some sampled farmers explain fertilizer as key ingredient to improve technical efficiency as compared to three decades back from today; they were not used fertilizer in their agricultural production, in which the production was lower. In rural area, especially in mixed farming system, oxen are important resource for draft power. Those they own oxen plough their farm land timely than those counterparts with no oxen. Conversely, oxen are affected by disease and shortage of water in the study area. The elasticity of seed is very low as compared to elasticity of labor, ox and fertilizer implying that seed has no greater influence on production of red pepper. This might be due to shortage of improved pepper seed varieties in the study area. In short, labor, fertilizer and oxen were statistically significant at $1 \%$ level of significance while seed was significant at $5 \%$. However, area allocated to red pepper production was statistically insignificant. This might be due to the information gathered from the farmers on the area allocated to red pepper production was based on their own assumptions.

\subsubsection{Estimation of farmer specific technical efficiency}

The result presented in table 5 shows that the estimated mean technical efficiency of red pepper producing farmers was about 80 ranging between 35 and 96.5 percent indicating that there is room to boost famer's level technical efficiency through using input variables and currently available technology. This implies that the farmers can increase the level of red pepper production on average by about 20 percent without incurring additional production inputs.

Table 5. Estimated technical efficiency of red pepper growing farmers

\begin{tabular}{ll}
\hline Description & TE estimates \\
\hline Mean & 0.8 \\
St. deviation & 0.114 \\
Minimum & 0.35 \\
Maximum & 0.965 \\
\hline
\end{tabular}

Source: Own computation (2017).

\subsubsection{Determinants of technical inefficiency}

Negative sign of inefficiency parameters shows that the variable reduces technical inefficiency or positively affects technical efficiency while positive sign shows increase technical inefficiency of red pepper producing farmers. Twelve inefficiency variables were presented in Table 6.

The results show that education, family size, farming experience, extension contact, access to credit, size of landholding, sex, distance to nearest market and access to off/non-farm occupation were negatively related with technical inefficiency while age, tropical livestock unit and fragmentation were positively related with technical inefficiency.

As priori expectation, coefficient of education in years of schooling is negative in red pepper production inefficiency and significant at $1 \%$ percent level of significance. This means that better educated farmer is technically more efficient than farmer with lower education level. In addition, education enhances the ability of 
farmers in inputs utilization which raises efficiency and develops flexibility in decision making. This result is consistent with the finding of Yami et al. (2013), Wassie (2014) and Ahmed et al. (2013).

The coefficient of family size in labor force units positively determines the technical efficiency of farmers as priori expectation. This means that the more family sizes by considering active labor force are important to perform such activities effectively and efficiently. This result is similar with the study by Ahmed et al. (2013). Coefficient of extension services was positive and statistically significant with technical efficiency at 5\% probability level as it was expected. This reflects the presence of intensive services about best available practices and efficiency enhancing technologies would shift the productivity level of farmers from relatively lower to higher. This result is in line with the study by Gelaw (2004), Hailsellasie (2005), Hailemaraim (2015) and Ahmed et al. (2013).

Coefficient of off/non-farm occupation has positive and significant effect on efficiency as it was expected. Off/non-farm incomes enable them to purchase or hire productive inputs. This result is consistent with the study by Hailemaraim (2015), Kitila and Alemu (2014) and it is in contrast with the study by Hailsellasie (2005).

Coefficient of distance to nearest market was positively related with technical efficiency and statistically significant at $5 \%$ percent level of significance which is not priori expectation. This implies that the farmers living in remote areas which are far from market place achieve their farming activities more efficiently than those counterparts living proximity the market. The reason for this might be farmers living near to urban area give due attention to off/non-farm activities than pepper production. This is in line with study by Getahun and Geta (2016). Table 6. Maximum likelihood of the inefficiency variables

\begin{tabular}{llll}
\hline Variable & Coefficient & Std. Err & $Z$ \\
\hline Constant & -0.611 & 1.6 & -0.38 \\
AGE & 0.086 & 0.062 & 1.39 \\
EDU & $-0.235^{* * *}$ & 0.063 & -3.74 \\
FAM & $-0.591^{* * *}$ & 0.23 & -2.57 \\
FE & -0.079 & 0.059 & -1.33 \\
EX & $-0.135^{* *}$ & 0.054 & -2.50 \\
CR & -1.251 & 0.805 & -1.55 \\
LS & -0.365 & 0.34 & -1.07 \\
TLU & 0.092 & 0.142 & 0.65 \\
SEX & -0.127 & 0.64 & -0.2 \\
FRAG & 0.431 & 0.289 & 1.49 \\
DSMT & $-0.476^{* *}$ & 0.224 & -2.12 \\
OFFARM & $-1.11^{*}$ & 0.646 & -1.72 \\
\hline
\end{tabular}

Source: Own computation (2017). * ${ }^{* *}$ and $* * *$ mean significant at levels of $0.1,0.05$ and 0.01 respectively.

\section{Conclusion}

The focus of this paper was to assess the technical efficiency of red pepper production in Dalocha district, Southern Ethiopia. The reason behind to focus on the efficiency of the production is to utilize the fixed resource efficiently by minimizing wastage to answer the increasing demand of the people from time to time for consumption of goods . The model used to estimate the technical efficiency and its determinants using one-stage estimation procedure in red pepper production was Cobb-Douglas stochastic frontier. The estimated stochastic production frontier model indicates that oxen power, seed, labor and fertilizer significant and positively affects the production level. Explicitly, increasing input variables would increase yield of red pepper. On the other hand, the variables such as education, family size, extension contact, distance to nearest market and off-farm income were significant and positively influence the technical efficiency.

The result shows that the mean technical efficiency of farmers was 80 ranges from 35 to $96.5 \%$. Based on the result generated, the famers are technically inefficient in red pepper production because they are operating below potential level of the crop. This implies that there is there is room to improve the efficiency level of farmers on average by $20 \%$ using current technology and available inputs.

\section{Limitation and Suggestions for Future Research}

This study focused only on farmers' level technical efficiency in red pepper production due to time, budget and facilities. For future time, there is a need of assessing the efficiency level of all crops produced in the area where crop production practiced. The reason behind is that, for ever increasing population in the area as well as in the countries, improving the level of efficiency of agricultural crops by improving the productivity of given inputs in agricultural crops is very essential to meet the demand side. At the time of data collection, the big challenge was shortage of recorded data overtime on the crop. Due to this, cross-sectional data was used to estimate efficiency level of farmers on red pepper production. Agricultural activities in the developing countries are highly depending on rainfall. This situation leads the other researchers to prefer the time series data for conducting the research in 
agriculture.

\section{Policy Implications}

The dose of fertilizer they used per unit of input was very low; oxen were going to die due to the shortage of water for drink; they face shortage of labor at the time of harvesting, because it overlap with other enterprises (i.e wheat); the advisory services provided by agents for the farmers were unequal and their education level in terms of years of schooling was varied. From this study, all these factors affect the productivity of red pepper production. Based on this, remedial measures need to be performed by increasing dose of fertilizer per unit of input, facilitate drinkable underground water for ox, improve labor productivity, facilitate fair extension accessibility for all farmers and encourage formal or informal education for them.

\section{References}

Ahmed, B., Haji, J. and Geta, E. 2013. Analysis of Farm Households Technical Efficiency in Production of Smallholder Farmers: The Case of Girawa District of Oromia region, Ethiopia. American-Eurasian Journal of Agricultural \& Environmental Science 13 (12): 1615-1621.

Alemnew, A. 2010. Market Chain Analysis of Red Pepper: The case of Bure Woreda, West Gojam Zone, Amhara National Regional State. MSc. Thesis, college of Agriculture, Haramaya University. Ethiopia. 91 pp.

Battese G. E. and Coelli T. J. 1995. Model for Technical Inefficiency Effects in a Stochastic Frontier Production Function for Panel Data. Empirical Econ., 20:325-332.

BOFED ( Bureau of Finance and Economic Development). 2012. Annual Statistical Abstract in Southern Nation, Nationalities and People Region.

Coelli, T.J., Rao, D.S.P. and Battese, G.E. 1998. An Introduction to Efficiency \& Productivity Analysis. Kluwer Academic Publishers, Boston, Dordrecht/London, P, 132 - 240.

CSA (Central Statistical Authority). 2008. Agricultural Statistics. 2008. Addis Ababa. 126 pp.

CSA (Central Statistical Authority). 2010. Agricultural Statistics. 2010. Addis Ababa. 58 pp.

CSA (Central Statistical Authority). 2012. Agricultural Statistics. 2012. Addis Ababa. 128 pp.

CSA (Central Statistical Authority). 2016. Agricultural Statistics. 2016. Addis Ababa. 121 pp.

Gelaw, F. 2004. Analysis of Technical Efficiency of Wheat Production: The case of Machakel District, East Gojam Zone, Amhara National Regional State. MSc. Thesis, college of Agriculture, Alemaya University. Ethiopia. $134 \mathrm{pp}$.

Getahun, W. and Geta, E. 2016. Technical Efficiency of Smallholder Wheat Farmers: The case of Welmera district of Central Oromia, Ethiopia. Journal of Development and Agricultural Economics 8(2):39-51.

Hailemaraim, L. 2015. Technical Efficiency in Teff Production: The Case of Bereh District of Oromia National Regional State. MSc. Thesis, college of Agriculture, Alemaya University. Ethiopia. 91 pp.

Hailsellasie, A. 2005. Analysis of Technical Efficiency in Sorghum production: The case of Raya-Azebo District of Tigray National Regional State. MSc. Thesis, college of Agriculture, Alemaya University. Ethiopia. 122 pp.

Herms, S. 2015. Business Opportunities Report Spices \#6 in the series written for the "Ethiopian Netherlands business event 5-6 November 2015, Rijswijk, The Netherlands"'

Kitila, G.M and Alemu, B.A 2014. Analysis of Technical Efficiency of Smallholder Maize Growing Farmers of Horo Guduru Wollega Zone, Ethiopia: A Stochastic Frontier Approach. Science, Technology and Arts Research Journal 3(3): 204- 2012.

Kodde, D.A. and Palm, C.F. 1986. Wald Criteria for Jointly Testing Equality and Inequality Restrictions. Econometrica 54(5):1243-1248.

Lemma, D., Fekadu, M., Harjit, S., Chemeda, F. and Ronald, S. 2008. Genetic Components and Heritability of Yield and Yield related Traits in Hot Pepper. Research Journal of Agriculture and Biological Science 4(6): 803-809.

Mohammed, B., Abdulsalam, Z. and Ahmed, B. 2015. Profitability in Chilli Pepper Production in Kaduna State, Nigeria. British Journal of Applied Science and Technology 12(3): 1-9.

Mohammed, B., Ahmed, B. and Abdulsalam, Z. 2015. Technical Efficiency of Chilli Pepper Production in Kaduna State, Nigeria. American Journal of Experimental Agriculture 9(15): 1-9.

Mussema, R. 2006. Analysis of Red Pepper Marketing: The case of Alaba and Siltie in Southern National Regional State. MSc. Thesis, college of Agriculture, Haramaya University. Ethiopia. 153 pp.

Sanusi, M. M. and Ayinde, I. A. 2013. Profitability of Pepper Production in Derived Savannah Zone of Ogun State, Nigeria. International journal of Agriculture and food security, 4:401-410.

Shih-wen, L., Yu-yu, C., Hsueh-ching, S., Andreas W. E., Sanjeet K., Ravza M., Albert R., Abdou, T., Victor, A. and Paul, A. G. 2013. Pepper (Capsicum spp.) Germplasm Dissemination by AVRDC - The World Vegetable Center: an Overview and Introspection. Chronica Horticulture 53(3):21-27.

Wassie, SB. 2014. Technical Efficiency of Major Crops in Ethiopia: Stochastic Frontier Model. Academia Journal 
of Agricultural Research 2(6): 147-153.

Yamane, T. I. 1967. Statistics: An introductory Analysis $2^{\text {nd }}$ Edition. New York, Harper and Row.

Yami, M., Solomon, T., Begna, B., Fufa, F., Alemu, T. and Alemu, D. 2013. Source of Technical Inefficiency of Smallholder Wheat Farmers in selected waterlogged areas of Ethiopia: A translog production function approach. African Journal of Agricultural Research 8(29):3930-3940.

\section{APPENDICES}

Appendix A. Tables

Appendix table 1: Conversion factors used to compute tropical livestock units (TLU)

\begin{tabular}{|lc|}
\hline Livestock category & Conversion factor \\
\hline Calf & 0.25 \\
Weaned calf & 0.34 \\
Heifer & 0.75 \\
Cow or ox & 1 \\
Donkey (adult) & 0.7 \\
Donkey (young) & 0.35 \\
Sheep or goat (adult) & 0.13 \\
Sheep or goat (young) & 0.06 \\
Chicken & 0.013 \\
Bull & 0.75 \\
\hline
\end{tabular}

Source: Stork et al. (1991)

Appendix table 2: Conversion factors for computation of man-equivalent

\begin{tabular}{ccc}
\hline Age group (years) & Male & Female \\
\hline$<10$ & 0 & 0 \\
$11-13$ & 0.2 & 0.2 \\
$14-16$ & 0.5 & 0.4 \\
$17-50$ & 1.0 & 0.8 \\
$>50$ & 0.7 & 0.5 \\
\hline
\end{tabular}

Source: Stork et al. (1991)

Appendix table 3: Estimated level of individual technical efficiency

\begin{tabular}{|l|l|l|l|l|l|l|l|}
\hline $\begin{array}{l}\text { Farm } \\
\text { no. }\end{array}$ & $\begin{array}{l}\text { Technical } \\
\text { efficiency }\end{array}$ & $\begin{array}{l}\text { Farm } \\
\text { no. }\end{array}$ & $\begin{array}{l}\text { Technical } \\
\text { efficiency }\end{array}$ & $\begin{array}{l}\text { Farm } \\
\text { no. }\end{array}$ & $\begin{array}{l}\text { Technical } \\
\text { efficiency }\end{array}$ & $\begin{array}{l}\text { Farm } \\
\text { no. }\end{array}$ & $\begin{array}{l}\text { Technical } \\
\text { efficiency }\end{array}$ \\
\hline 1 & 0.844724 & 44 & 0.837329 & 87 & 0.863087 & 130 & 0.916733 \\
\hline 2 & 0.782435 & 45 & 0.888621 & 88 & 0.894509 & 131 & 0.578681 \\
\hline 3 & 0.899631 & 46 & 0.452298 & 89 & 0.760034 & 132 & 0.821819 \\
\hline 4 & 0.350181 & 47 & 0.854959 & 90 & 0.855098 & 133 & 0.885747 \\
\hline 5 & 0.470818 & 48 & 0.739373 & 91 & 0.839852 & 134 & 0.502405 \\
\hline 6 & 0.68685 & 49 & 0.683863 & 92 & 0.879901 & 135 & 0.903296 \\
\hline 7 & 0.846207 & 50 & 0.88194 & 93 & 0.885358 & 136 & 0.871639 \\
\hline 8 & 0.632921 & 51 & 0.760972 & 94 & 0.848522 & 137 & 0.836277 \\
\hline 9 & 0.828835 & 52 & 0.593318 & 95 & 0.720917 & 138 & 0.918836 \\
\hline 10 & 0.681689 & 53 & 0.863002 & 96 & 0.86351 & 139 & 0.910464 \\
\hline 11 & 0.856804 & 54 & 0.590065 & 97 & 0.84691 & 140 & 0.870279 \\
\hline 12 & 0.883564 & 55 & 0.77222 & 98 & 0.814472 & 141 & 0.854901 \\
\hline 13 & 0.606889 & 56 & 0.704064 & 99 & 0.891852 & 142 & 0.846886 \\
\hline 14 & 0.575721 & 57 & 0.74919 & 100 & 0.845441 & 143 & 0.848815 \\
\hline 15 & 0.780305 & 58 & 0.821156 & 101 & 0.794032 & 144 & 0.863517 \\
\hline 16 & 0.845187 & 59 & 0.876573 & 102 & 0.815775 & 145 & 0.932108 \\
\hline 17 & 0.900952 & 60 & 0.760154 & 103 & 0.719784 & 146 & 0.906696 \\
\hline 18 & 0.658033 & 61 & 0.846115 & 104 & 0.835091 & 147 & 0.846502 \\
\hline 19 & 0.964686 & 62 & 0.624068 & 105 & 0.867083 & 148 & 0.866381 \\
\hline 20 & 0.604123 & 63 & 0.648199 & 106 & 0.758043 & 149 & 0.943648 \\
\hline 21 & 0.851808 & 64 & 0.753887 & 107 & 0.843207 & 150 & 0.926202 \\
\hline 22 & 0.777993 & 65 & 0.596227 & 108 & 0.91219 & 151 & 0.95625 \\
\hline 23 & 0.874689 & 66 & 0.662603 & 109 & 0.826544 & 152 & 0.840512 \\
\hline 24 & 0.566073 & 67 & 0.681966 & 110 & 0.784938 & 153 & 0.626525 \\
\hline
\end{tabular}




\begin{tabular}{|l|l|l|l|l|l|l|l|}
\hline $\begin{array}{l}\text { Farm } \\
\text { no. }\end{array}$ & $\begin{array}{l}\text { Technical } \\
\text { efficiency }\end{array}$ & $\begin{array}{l}\text { Farm } \\
\text { no. }\end{array}$ & $\begin{array}{l}\text { Technical } \\
\text { efficiency }\end{array}$ & $\begin{array}{l}\text { Farm } \\
\text { no. }\end{array}$ & $\begin{array}{l}\text { Technical } \\
\text { efficiency }\end{array}$ & $\begin{array}{l}\text { Farm } \\
\text { no. }\end{array}$ & $\begin{array}{l}\text { Technical } \\
\text { efficiency }\end{array}$ \\
\hline 25 & 0.866307 & 68 & 0.598454 & 111 & 0.899476 & 154 & 0.860449 \\
\hline 26 & 0.904235 & 69 & 0.550951 & 112 & 0.876897 & 155 & 0.914405 \\
\hline 27 & 0.767208 & 70 & 0.890202 & 113 & 0.921252 & 156 & 0.881401 \\
\hline 28 & 0.71621 & 71 & 0.785973 & 114 & 0.877091 & 157 & 0.960786 \\
\hline 29 & 0.584744 & 72 & 0.848387 & 115 & 0.86623 & 158 & 0.807562 \\
\hline 30 & 0.712678 & 73 & 0.697765 & 116 & 0.863083 & 159 & 0.935617 \\
\hline 31 & 0.756868 & 74 & 0.682502 & 117 & 0.828902 & 160 & 0.797018 \\
\hline 32 & 0.80145 & 75 & 0.933188 & 118 & 0.786707 & 161 & 0.874001 \\
\hline 33 & 0.636233 & 76 & 0.845975 & 119 & 0.839201 & 162 & 0.890205 \\
\hline 34 & 0.63601 & 77 & 0.824999 & 120 & 0.871639 & 163 & 0.919749 \\
\hline 35 & 0.796135 & 78 & 0.755283 & 121 & 0.927652 & 164 & 0.816594 \\
\hline 36 & 0.877278 & 79 & 0.900621 & 122 & 0.921114 & 165 & 0.831817 \\
\hline 37 & 0.864268 & 80 & 0.869786 & 123 & 0.822161 & 166 & 0.741228 \\
\hline 38 & 0.828109 & 81 & 0.661131 & 124 & 0.81889 & 167 & 0.885234 \\
\hline 39 & 0.742266 & 82 & 0.838543 & 125 & 0.886474 & 168 & 0.79519 \\
\hline 40 & 0.878432 & 83 & 0.926776 & 126 & 0.855703 & 169 & 0.846196 \\
\hline 41 & 0.850027 & 84 & 0.825216 & 127 & 0.677401 & 170 & 0.794663 \\
\hline 42 & 0.459738 & 85 & 0.792788 & 128 & 0.848777 & & \\
\hline 43 & 0.86442 & 86 & 0.840041 & 129 & 0.881149 & & \\
\hline
\end{tabular}

Source: Own computation (2017)

Appendix table 4. Distribution of technical efficiency of red pepper producers

\begin{tabular}{lll}
\hline Range of technical efficiency & Frequency & Percent \\
\hline$<=0.5$ & 5 & 2.94 \\
$0.51-0.6$ & 10 & 5.88 \\
$0.61-0.7$ & 18 & 10.59 \\
$0.71-0.8$ & 30 & 17.65 \\
$0.81-0.9$ & 88 & 51.76 \\
$0.91-0.965$ & 19 & 11.18 \\
Total & 170 & 100 \\
\hline
\end{tabular}

Source: Own computation (2017) 